\title{
Globalization Is Dead! Long Live Globalization!
}

\begin{abstract}
The central paradox of our times is that even though globalization has dramatically improved the human condition over the past few decades, many are now predicting its imminent demise. How did this happen? Because of three key strategic mistakes made by the West in its management of globalization.
\end{abstract}

We have all heard the refrain: "The King is dead; Long live the King!" The newest version of this is "Globalization is dead; Long live globalization!" This new refrain captures well the central paradox about our times. Globalization has done more to improve the human condition over the past few decades than any other force in human history. Yet, instead of celebrating globalization, many in the world are predicting its imminent demise, especially in the West, even though it was the West that launched our foray into globalization.

How do we explain this paradox? Why has the West turned against its most benevolent contribution to humanity? The simple explanation is that the West has made three strategic mistakes in its management of globalization. More accurately, the mistakes have been by the largest Western power, the United States. Nonetheless, these American mistakes have been compounded by the failure of the second most powerful Western economic force, the European Union, to help and guide the US when the US was making these three strategic mistakes. The passivity of the Europeans contributed significantly to the problem.

\section{Three Mistakes the US Made}

So what were the three strategic mistakes made by the US? The first mistake was made by the elites, the top $1 \%$ in the US. They reaped huge rewards from globalization, but they failed to help the lower half of Americans who suffered from the inevitable disruptions (or, more accurately, "creative destruction") caused by globalization. The second mistake was to weaken government and governmental institutions when they

Originally published in Dec 1, 2020 
should have been strengthened instead. This mistake was made during the famous Reagan-Thatcher revolution when Ronald Reagan famously said, "Government is not the solution to our problem, government is the problem." The consequences of this belief were disastrous. Three decades of defunding, delegitimization, and demoralization of key public service agencies followed it. The third mistake was for the top $1 \%$ to create a functional plutocracy in America. What is the essential difference between a democracy and a plutocracy? In a democracy, you have a government of the people, by the people, and for the people. In a plutocracy, you have a government of the $1 \%$, by the $1 \%$, and for the $1 \%$. Most Americans react with disbelief to the claim that their society has functionally become a plutocracy. Yet eminent figures like Paul Volcker, Joseph Stiglitz and Martin Wolf has confirmed this development.

Another paradox surrounds these three strategic mistakes made by the US. The country with the largest strategic thinking industry in the world (embedded in the universities, think tanks, consultancies, non-governmental organizations) is the US. Yet, even though these are three major strategic mistakes, there is no public acknowledgment in the American body politic that these mistakes have been made. Nor has there been much discussion of it in the very influential op-ed pages of leading newspapers like the New York Times and Washington Post, the Wall Street Journal and The Economist. Future historians will have to investigate and explain this curious phenomenon of massive self-ignorance in the American body politic.

Since many Americans would vehemently deny that these strategic mistakes have been made, it is necessary to explain in greater detail how each of these mistakes was made This is what this essay will try to accomplish, while also suggesting some solutions to the problems and mistakes that are identified. This essay will also end with the optimistic conclusion that all three strategic mistakes can be rectified and the US can emerge again as the number one champion of globalization, as it once was. After that, Tom Friedman, Jagdish Bhagwati and Martin Wolf can come out with new editions of The World is Flat, In Defense of Globalization and Why Globalization Works in 2021.

\section{Strategic Mistake One}

The first strategic mistake was the failure of the elites in the US to protect the working classes from the inevitable disruptions caused by globalization. Why did this happen? Was it a result of the greed and callousness of the elites in America? Or were there larger historical trends that also contributed to this final strategic mistake?

As usual, the answers to these questions are complicated. Yet, it is also clear that larger historical trends contributed to this mistake. Future historians will see more clearly than we do that the working classes in America suffered because of an unfortunate coincidence of two major moments of history. The first moment was "The End of History" moment captured in the famous essay by Francis Fukuyama. The second moment was "The Return of History" moment, also in the early 1990s, when China and India decided to wake up. The unfortunate result of the coincidence 
of these two moments is that the West chose to go sleep at precisely the moment when China and India (and the rest of Asia) decided to wake up.

How and why this happened has been documented in my book, Has the West Lost It? Here's a brief summary. Francis Fukuyama didn't intend to put the West to sleep. However, when he suggested that Western civilization had reached the end of the road of political and economic evolution, he certainly created the impression among many Western minds, including some leading minds, that Western societies no longer needed to make any serious structural or strategic adjustments to a new world. Only non-western societies had to adjust and adapt. This message inevitably created arrogance, hubris, and complacency in Western societies. As a result, almost no one in the West noticed that the moment the West chose to go to sleep was the moment when it should have woken up instead.

Wake up to what? The West should have seen in the early 1990s that after having essentially gone to sleep for almost two hundred years, China and India decided to wake up. Why was their awakening significant? From the year 1 to 1820 , the two largest economies in the world were China and India (see Fig. 1). Hence, when China and India decided to once again wake up, it was inevitable that they would shake the world. As China emerged as a manufacturing superpower, producing better quality goods at lower prices, it was inevitable that some industries in the US would shut down and American workers would lose their jobs. None of this should have been surprising. It is called "creative destruction" in Western economic theory.

Let me acknowledge here that there is some debate among economists whether the emergence of the new industries in China caused job losses in the US. Some economists reject this claim. Yet there are at least two strong and credible economists who have documented how American workers lost jobs as a result of new competition from China. They are Daron Acemoglu of Massachusetts Institute of Technology and Robert Scott of the Economic Policy Institute. Scott and Mokhiber (2018) state that 3.4 million jobs were lost in the US post 2001, while Acemoglu et al. (2016) estimate

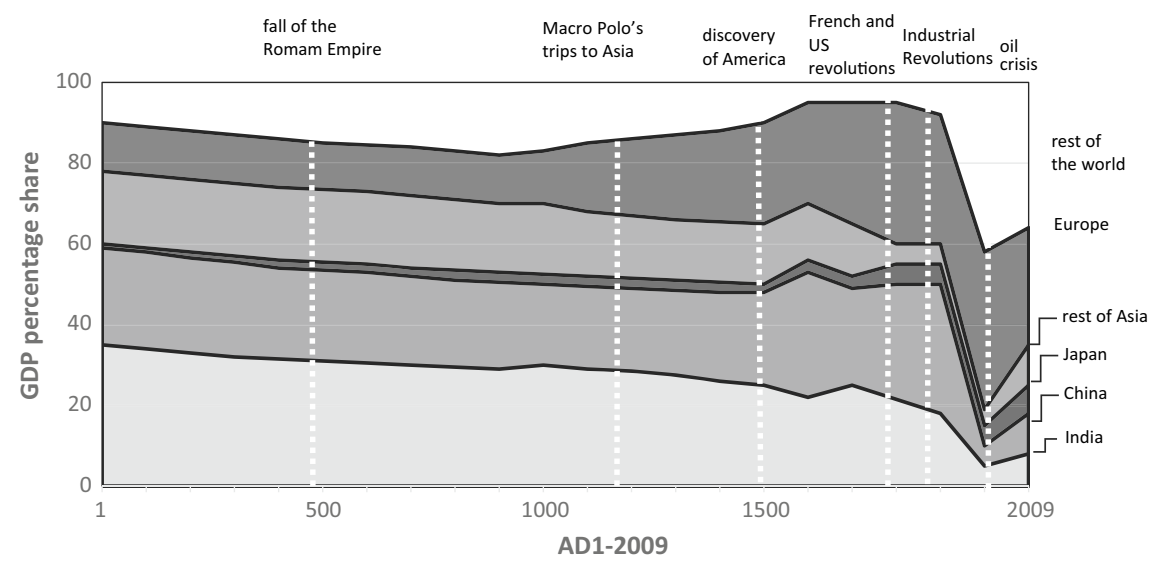

Fig. 1 Share of total world GDP (Mahbubani 2018) 
a 2-2.4 million job loss from 1999 to 2011 due to Chinese import competition (Scott and Mokhiber 2018; Acemoglu et al. 2016)

Significantly, while all this was happening, the Clinton Administration made no effort to launch programs to help workers who lost jobs. After the Clinton Administration left office in January 2001, there was once again an unfortunate coincidence of two historical events. The big event that the Bush Administration paid attention to was the attack on the US by Osama bin Laden on September 11, 2001 (remembered as 9/11). Quite naturally, this caused a lot of anger in the American body politic. Consequently, the Bush Administration became involved in two major wars in Afghanistan starting October 7, 2001, and in Iraq starting March 20, 2003. In their anger over the 9/11 attacks, the American people and policymakers didn't notice that something more significant and earth-changing happened in 2001: China's entry into the World Trade Organization (WTO) on December 11, 2001.

As more Chinese exports to the US and the rest of the world obtained dutyfree access, it was inevitable that Chinese exports would surge following their entry into the WTO. Indeed, Fig. 2 shows clearly how China's trade with the rest of the world, including the US and Europe, increased significantly after 2001. Clearly, if US policymakers had been more vigilant, they would have paid attention to the increasing plight of American workers. Sadly, they didn't. So this was strategic mistake number one: ignoring the needs and interests of the working classes as they experienced "creative destruction" caused by the return of China, India, and the rest of Asia.

\section{China: total global trade (US\$ Billions)}

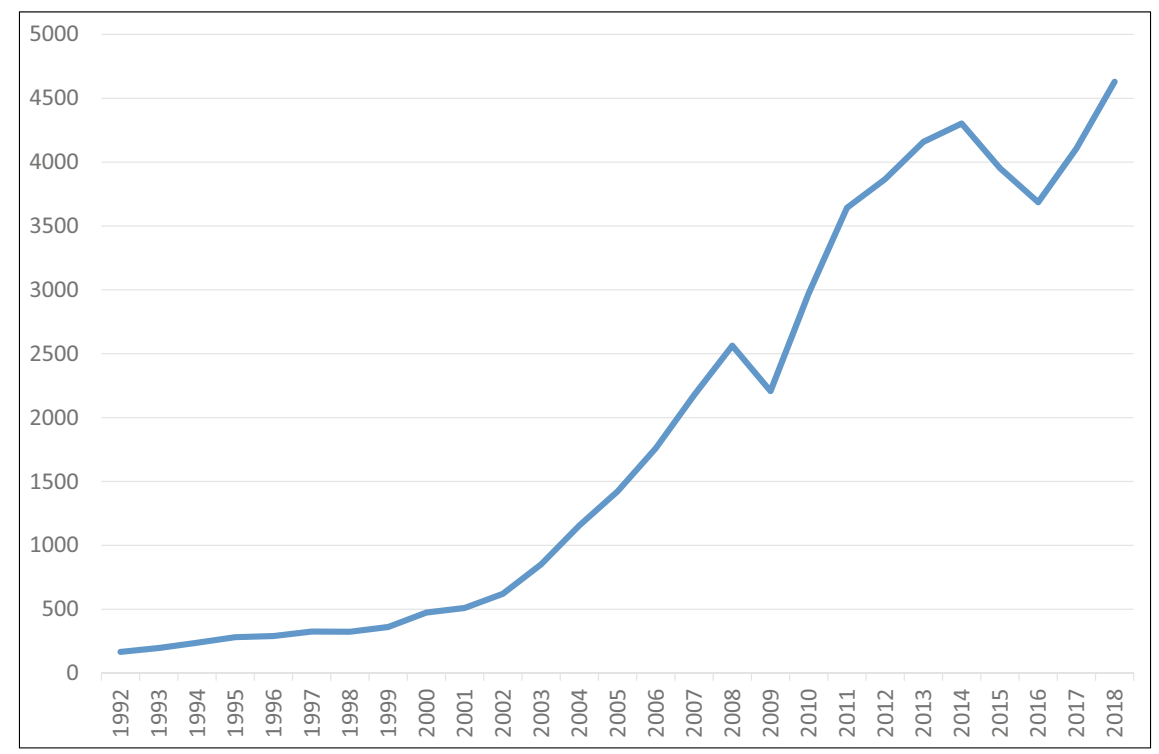

Fig. 2 China: increase in global trade, 1992-2018 (World Bank. https://wits.worldbank.org/Def ault.aspx? ?lang=en) 


\section{Strategic Mistake Two}

Strategic mistake one was clearly compounded by strategic mistake two: the weakening of government institutions, especially in the US. The Reagan-Thatcher revolution of the 1980s left behind two intellectual legacies. The first was the belief that markets knew best. Hence, if an economic problem emerged, the markets would find a solution to it. The second was the belief, as indicated earlier, that "Government is not the solution to our problem, government is the problem." Hence, the idea that governments should play a role in helping workers hurt by economic competition was considered taboo. The markets would create and provide new jobs to workers.

Curiously, even though in theory the Reagan Administration was not in favor of government interventions against market forces, the Reagan Administration intervened at least twice when it believed that free-market forces would hurt American companies. When American automobile companies complained that they could not compete against Japanese automobile manufacturers, the American government arm-twisted the Japanese government into accepting "Voluntary Export Restraints" (VERs) on Japanese car exports to the US. The VERs were implemented in 1981. In addition to VERs, the Reagan Administration also took a second step to protect American companies from Japanese competition: it arm-twisted the Japanese government into accepting a significant upward revaluation of the yen from 240 to the dollar in 1985 to 120 to the dollar in 1988. Clearly, this made Japanese exports uncompetitive. As an aside, let me mention that one unintended positive outcome of the forced revaluation of the yen was that the Japanese companies began to manufacture more in the US and in third countries, including ASEAN countries.

The Reagan Administration, therefore, left behind a contradictory legacy in the US. In theory, it opposed government interventions in markets. In practice, as demonstrated in its actions against Japanese industries, the Reagan Administration actually supported government interventions. Unfortunately, the government intervention it favored was "negative" intervention: using strong-arm tactics to stop Japanese competition. It did not carry out any "positive" intervention, like retraining workers who lost jobs in the face of economic competition.

In this regard, the American attitude of letting market forces take care of creating new jobs is different from both European and Asian approaches. Indeed, the governments of the European Union and several East Asian governments (including Japan, South Korea, Taiwan, and Singapore) invest in worker-training programs. This American antipathy to have government intervention in worker-training programs also extends to opposition to trade unions to protect worker interests. Singapore discovered this when it laid out the red carpet for American MNCs to invest in Singapore in the 1960s and 1970s. These American MNCs insisted that they would only invest in Singapore if the Singapore government prevented Singaporean workers from joining trade unions because, in their eyes, trade unions interfered with market forces. It took some persuasion but, in the end, the American MNCs accepted the Singapore government's argument that the Singapore trade unions could help to create better relations between workers and management in the factories. 
This American disdain for setting up schemes and institutions to help workers was also part of a larger philosophical outlook which was captured in a famous statement made by Milton Friedman: "the business of business is business." In short, the only thing that mattered was the bottom line of the companies. If workers had to be fired to improve the profitability of the companies, so be it. Profits were more important than people.

It would be unfair to blame only Milton Friedman for this ethos. One of America's most august institutions is the Harvard Business School (HBS). For several generations, HBS also spread the philosophy that the primary responsibility of firms was to generate greater profits. Hence, only one stakeholder mattered: the shareholders. All the other stakeholders, including the workers and the community, were deemed to be less important. By contrast, the World Economic forum advises firms to pay attention to multiple stakeholders, including "employees, customers, suppliers, local communities and society at large." World Economic Forum (2019).

\section{Strategic Mistake Three}

This antipathy of the American business elites to paying attention to larger societal concerns may also be a contributing factor to the third strategic mistake made by the US: the creation of a functional plutocracy that has effectively undermined the American democratic system. In short, the US has gone from having a government of the people, by the people, and for the people toward having a government of the $1 \%$, by the $1 \%$, and for the $1 \%$. What is truly lacking is that even though there is overwhelming evidence that the US has become a plutocracy, there is a powerful resistance to calling the US a plutocracy, even though eminent voices like the late Paul Volcker, Joseph Stiglitz and Martin Wolf have done so. Since there is a lot of political and intellectual resistance to "calling a spade a spade" on this issue, I devoted a whole chapter in my book, Has China Won? to explain in careful detail how the US has evolved toward becoming a plutocracy.

Significantly, some of the most wealthy Americans have begun to acknowledge this. Ray Dalio runs the largest, most successful hedge fund in the world, which has succeeded through rigorous empirical research. Dalio has now applied this research to understanding poverty and inequality in America. On his LinkedIn page, Dalio spells out the dramatic decline in the living standards of the majority of Americans and points out that "most people in the bottom $60 \%$ are poor" and cites "a recent Federal Reserve study [that showed that] $40 \%$ of all Americans would struggle to raise $\$ 400$ in the event of an emergency (Dalio 2019). Worse, Dalio notes that "they are increasingly getting stuck being poor... the odds of someone in the bottom quintile moving up to the middle quintile or higher in a 10-year period... declined from about $23 \%$ in 1990 to only 14\% as of 2011." The data on social deterioration in America is undeniable. It undercuts the claims that America is a society where hard work brings rewards. For most people, the rewards have dried up. The platitude "virtue is its own reward" turns out to be grimly and limitingly true. 


\section{America's Road to Plutocracy}

Why has America performed so badly? The simple explanation is that it demonstrates that a fundamental change has taken place in America's political arrangements, without the American people noticing it. Every two to four years Americans go to the polls to elect their congressmen, senators, governors, and state legislative assembly representatives. And yet, under the surface guise of a functioning democracy, with all the rituals of voting, America has become a society run by a moneyed aristocracy that uses its money to make major political and social decisions. As a result, this class has been able to enact the greatest transfer of wealth that has ever taken place in American society.

The great American philosopher, John Rawls, warned of this danger. He said, "The liberties protected by the principle of participation lose much of their value whenever those who have greater private means are permitted to use their advantages to control the course of public debate." Almost 50 years ago, he warned that if those with "greater private means" are allowed to control the course of public debate, American democracy would be subverted.

This is exactly what happened when the US Supreme Court overturned, in a landmark ruling in Citizens United v. Federal Election Commission (FEC) (2010) and in other decisions, many of the legislative restraints on the use of money to influence the political process. The impact of this and other Supreme Court decisions was monumental. Effectively, they helped to transform the American political system. Martin Wolf says that "the Supreme Court's perverse 2010 'Citizens United' decision held that companies are persons and money is speech. That has proved a big step on the journey of the US toward becoming a plutocracy."

Two Princeton University professors have documented how ordinary American citizens have lost their political power and influence. Martin Gilens and Benjamin Page studied the relative influence that the views of average Americans and massbased interest groups have on policy outcomes versus the views of the economic elite in 1779 cases. They found that,

economic elites and organized groups representing business interests have substantial independent impacts on US government policy, while average citizens and mass-based interest groups have little or no independent influence. [...] When the references of economic elites and the stands of organized interest groups are controlled for, the preferences of the average American appear to have only a minuscule, near-zero, statistically non-significant impact upon public policy. [. . .] Furthermore, the preferences of economic elites (as measured by our proxy, the preferences of "affluent" citizens) have far more independent impact upon policy change than the preferences of average citizens do. [. . .] In the United States, our findings indicate, the majority does not rule-at least not in the causal sense of actually determining policy outcomes. (Gilens and Page 2014)

They reach the following alarming conclusion:

Americans do enjoy many features central to democratic governance, such as regular elections, freedom of speech and association, and a widespread (if still contested) franchise. But we believe that if policymaking is dominated by powerful business organizations and a 
small number of affluent Americans, then America's claims to being a democratic society are seriously threatened.

In the past, the broad middle classes of America had a strong say in determining the fundamental directions of American society. Today, they no longer do. The decisions of the US Congress are not determined by the voters; they are determined by the funders. As a result, America is becoming functionally less and less of a democracy, where all citizens have an equal voice. Instead, it looks more and more like a plutocracy, where a few rich people are disproportionately powerful.

A 2018 study by scholars Alexander Hertel-Fernandez, Theda Skocpol and Jason Sclar of the School of International and Public Affairs, Columbia University, further argued that

since the mid-2000s, newly formed conservative and progressive Donor consortia—above all the Koch seminars [founded by brothers Charles and David Koch] and the DA [Democracy Alliance] — have magnified the impact of wealthy donors by raising and channeling ever more money not just into elections but also into full arrays of cooperating political organizations. ... The Koch seminars... allowed donations to be channeled into building a virtual third political party organized around AFP [Americans for Prosperity], an overarching political network able not only to electorally support the Republican Party but also to push and pull its candidates and office holders in preferred ultra-free-market policy directions... To the degree that wealthy donor consortia have succeeded in building organizational infrastructures, they have shifted the resources available for developing policy proposals, pressing demands on lawmakers, and mobilizing ordinary Americans into politics... When plutocratic collectives impose new agendas on political organizations seeking to attract financial resources, the funders reshape routines, goals, and centers of power in US politics well beyond the budgetary impact of particular grants. (Hertel-Fernandez et al. 2018)

The authors thus conclude:

Our analysis of the Koch and DA consortia highlights that a great deal of big-money influence flows through mechanisms other than individual or business donations to the electoral and lobbying operations...To understand how the wealthy are reshaping US politics, we need to look not just at their election and lobbying expenditures but also at their concerted investments in many kinds of political organizations operating across a variety of fields and functions. Only in this way can we account for the stark inequalities in government responsiveness documented by researchers such as Martin Gilens, Larry Bartels and Benjamin Page.

In theory, the American people would revolt if their votes were taken away from them. Yet, their votes have effectively been hijacked by the rich-but most Americans haven't noticed it yet. Anand Giridharadas, a former New York Times columnist, has documented in great detail in Winners Take All how the dream of the American middle class has effectively evaporated. As he says:

A successful society is a progress machine. It takes in the raw material of innovations and produces broad human advancement. America's machine is broken. When the fruits of change have fallen on the United States in recent decades, the very fortunate have basketed almost all of them. For instance, the average pretax income of the top tenth of Americans has doubled since 1980, that of the top 1 percent has more than tripled, and that of the top 0.001 percent has risen more than seven fold-even as the average pretax income of the bottom half of Americans has stayed almost precisely the same. These familiar figures amount to three and a half decades' worth of wondrous, head-spinning change with zero impact on the average pay of 117 million Americans. (Giridharadas 2018) 
American scholars on political systems are fond of quoting Lord Acton's famous quip: "Power corrupts. Absolute power corrupts absolutely." After quoting him, they probably whisper under their breaths, "Thank God, we are a democracy with separation of powers. This couldn't happen to us." All those scholars should consider this variation on Lord Acton instead: "Money corrupts. Absolute money corrupts absolutely."

The corrupting effect of money on political processes should be more prominently highlighted in American political discourse. In most societies, when individuals or corporations use money to influence public policy decisions, it is called out corruption. Even people in third world countries that suffer from widespread corruption know it is illegal, though they often do not have the means to oppose it. But in America, it is not considered corruption to use money to influence public policy decisions because the Supreme Court legalized it.

In legalizing the use of massive amounts of money to influence public policy decisions, the Supreme Court had clearly ignored the advice of John Rawls, who warned that if "those who have greater private means are permitted to use their advantages to control the course of public debate," this would be the corrupting result:

Eventually, these inequalities will enable those better situated to exercise a larger influence over the development of legislation. In due time they are likely to acquire a preponderant weight in settling social questions, at least in regard to those matters upon which they normally agree, which is to say in regard to those things that support their favored circumstances. (Rawls 1999)

This is precisely what has happened over the past few decades: the affluent have gained "preponderant weight... in regard of those things that support their favored circumstances." There has been a relative transfer of wealth and political power from the vast majority of America's population to a privileged superminority. Hence, there is no doubt that America has become a plutocracy.

\section{Simple Solutions and Hard Decisions}

So to quote Lenin, "What is to be done?" in response to these three strategic mistakes. The good news is that they can be fixed. Here are three simple steps that can be taken. The first step is for the West, especially the US, to acknowledge that the wounds it has suffered from globalization are self-inflicted, as documented in the three mistakes made. The second step, a natural consequence of the first, is to take remedial measures against the self-inflicted wounds. The third step would be for the West and the East, especially the US and China, to reach a new comprehensive understanding of how to cooperate in managing the common challenges faced in globalization.

Sadly, even though these steps are "simple" in theory, in practice they will be difficult to implement. The first step may be the hardest to take. Most societies, including the US, would prefer to believe that other societies are responsible for 
their problems. Hence, when Donald Trump launched his trade war against China, few American voices spoke up to say the undeniable truth: America's trade deficits were a result of domestic, not external, factors. The imbalance between consumption and savings was the main reason for the trade deficit. Indeed, even if the trade deficit of the US with China went down, its trade deficit with the rest of the world would not go down. This is exactly what happened between 2017 and 2019, the years of the Trump trade war. In 2019, the US deficit with China dropped from USD 375 billion in 2017 to USD 345 billion in 2019, but its overall trade deficit with the world went up from USD 792 billion in 2017 to USD 854 billion.

Therefore, unless the US acknowledges that its problems with globalization are the result of self-inflicted wounds, it will be difficult for it to take the necessary remedial steps, especially the rebuilding of strong and effective institutions to manage the inevitable challenges of globalization and the reversal of the moves (including the Supreme Court decision legitimizing the unlimited amount of corporate funding for political donations) that have led to the development of plutocracy in the US. In short, the first step and second step are connected. Just as we cannot cure a medical ailment until we acknowledge that we have an ailment, the US cannot reverse the problems it has developed with globalization until it acknowledges that its problems are the result of self-inflicted wounds.

While it is working on a difficult first two steps, the US can begin taking action on the third: reaching a new understanding with China on how to manage the challenges of globalization together. Here too, in theory, the interests of the US and China in this area may appear irreconcilable. However, as I have documented in great length in the final chapter of Has China Won?, there are no fundamental conflicts of interest between the long-term interests of the US and China.

Indeed, there are five "non-contradictions" between the US and China, and here's the first non-contradiction. If the primary goal of the US government is to improve the well-being of the American people (as it should be) and if the primary goal of the Chinese government is to improve the well-being of the Chinese people (as it should be), there is no fundamental contradiction between these two goals. Indeed, both governments are more likely to succeed in achieving their respective goals, if they cooperate, rather than engage in a zero-sum game of geopolitical competition. The main obstacle to such win-win cooperation is a belief among many influential voices in Washington DC that the primary goal of the US should be to preserve "primacy" in the global system. However, between "primacy" and "people", clearly the interests of the American people are more important. Sheer common sense makes this clear.

The election of Joe Biden as President provides a tremendous opportunity to reset the US-China relationship. In theory, Biden's hands are tied since a rock solid anti-China consensus has gripped the Washington elite. However, if Biden is politically shrewd, he can navigate this difficult domestic environment in the US by appearing publicly critical of China while privately enhancing cooperation in the areas of mutual benefit between the US and China. He could use the excuse of COVID-19 to remove some trade sanctions against China. This would encourage China to buy more from America, especially in agricultural products. If the farmers in the mid-West swing toward supporting Biden, he would have undercut a significant 
base from the Republicans before the 2022 and 2024 elections. Hence, paradoxically, economic cooperation with China could help Biden win votes domestically.

In short, even though it appears inconceivable in today's political context that the US and China can cooperate for mutual benefit, the reality is that they can and should do so, especially after the election of Joe Biden. Both sides, especially both governments, should not lose sight of the fact that their primary responsibility is to improve the well-being of their people. They can achieve this by working with each other, not against each other.

\section{References}

Mahbubani K (2018) Has the West lost it? A provocation. Penguin UK, London, p 5

Scott RE, Mokhiber Z (2018) The China toll deepens. Economic Policy Institute, Washington, DC. https://epi.org/156645

Acemoglu D, Autor D, Dorn D, Hanson GH, Price B (2016) Import competition and the great US employment sag of the 2000s. J Labor Econ 34(S1):S141-S198

World Bank. World Integrated Trade Solution. https://wits.worldbank.org/Default.aspx?lang=en

World Economic Forum (2019) Davos Manifesto 2020: The Universal Purpose of a Company in the Fourth Industrial Revolution, 2 December 2019. https://www.weforum.org/agenda/2019/12/ davos-manifesto-2020-the-universal-purpose-of-a-company-in-the-fourth-industrial-revolution/

Dalio R (2019) Why and how capitalism needs to be reformed (Part 1), LinkedIn, April 4, 2019. https://www.linkedin.com/pulse/why-how-capitalism-needs-reformed-ray-dalio/. See also Board of Governors of the Federal Reserve System, Report on the Economic Well-Being of U.S. Household in 2017, May 2018. https://www.federalreserve.gov/publications/files/2017-reporteconomic-well-being-us-households-201805.pdf, quoted in Dalio

Gilens M, Page BI (2014) Testing theories of american politics: elites, interest groups, and average citizens. Perspect Polit 12(30:564-581. https://scholar.princeton.edu/sites/default/files/mgilens/ files/gilens_and_page_2014_-testing_theories_of_american_politics.doc.pdf

Hertel-Fernandez A, Skocpol T, Sclar J (2018) When political mega- donors join forces: how the Koch network and the democracy alliance influence organized U.S. politics on the right and left. Stud Am Polit Dev 32(2)

Giridharadas A (2018) Prologue. In: Winners take all: the elite charade of changing the world. Alfred A. Knopf, New York

Rawls J (1999) A theory of justice, rev. Belknap Press, Cambridge, MA, p 225 
Open Access This chapter is licensed under the terms of the Creative Commons AttributionNonCommercial-NoDerivatives 4.0 International License (http://creativecommons.org/licenses/bync-nd/4.0/), which permits any noncommercial use, sharing, distribution and reproduction in any medium or format, as long as you give appropriate credit to the original author(s) and the source, provide a link to the Creative Commons license and indicate if you modified the licensed material. You do not have permission under this license to share adapted material derived from this chapter or parts of it.

The images or other third party material in this chapter are included in the chapter's Creative Commons license, unless indicated otherwise in a credit line to the material. If material is not included in the chapter's Creative Commons license and your intended use is not permitted by statutory regulation or exceeds the permitted use, you will need to obtain permission directly from the copyright holder.

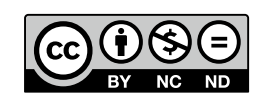

